https://doi.org/10.46344/JBINO.2021.v10i03.27

\title{
MANAGEMENT OF TAMAKA SHWASA (BRONCHIAL ASTHMA) IN CHILDREN THROUGH AYURVEDA
}

\section{Dr Jayprakash Ashok Khairnar}

Associate Prof., Department of Kaumarbhritya, Smbt College of Ayurved, Dhamangaon, Ghoti, Nashik, Maharashtra, India - 422403

\section{ABSTRACT}

Bronchial Asthma is a chronic inflammatory condition of the lung airways resulting in episodic airflow obstruction.[1] and Ayurveda address it as "Tamaka Shwasa." Tamaka Shwasa is a type of Shwasa Roga affecting the Pranavaha Srotas. Pranavilomata (abnormal breathing pattern), Hridaya Pidana (chest tightness), Ruddha Shwasa (difficulty in breathing), Ghurghurukama (wheeze) and Kasa (cough) are the cardinal features of the disease. [2] So the sign and symptom of Tamaka Shwasa are very similar to Bronchial Asthma. 


\section{INTRODUCTION}

Bronchial asthma is a common and life threatary problem affecting school children and adolescents. The flare-up of asthma may lead to impaired daily function and absence from school. Asthma is the most common chronic lower respiratory disease in childhood throughout the world and Ayurveda address it as "Tamaka Shwasa." There are five kinds of Shwasa: Kshudra, Tamaka, Chhinna, Maha and Urdhava. Tamaka Shwasa is a type of Shwasa Roga affecting the Pranavaha Srotas. Vata moving in the reverse order pervades the channels (of vital breath), afflicts the neck and head, and stimulates Kapha (phlegm) to cause Margavarodha (blockage of respiratory passage) by producing broncho constriction. Tamaka Shwasa classified as Vata Pradhana and Kapha Pradhana. Tamaka Shwasa is a "Swatantra" Vyadhi having its own etiological factors, patho-physiology and management. It is mentioned as Yapya Vyadhi[3] i.e. a disease of chronic nature in Charaka Samhita, while Sushruta considered it as Krichchra Sadhya Vyadhi. The parallel disease entity in contemporary medical science to this disorder is Bronchial Asthma. The prevalence of Bronchial Asthma has increased continuously since the 1970s, and now affects an estimated 4 to $7 \%$ of the people worldwide. At the age of six to seven years, the prevalence ranges from $4-32 \%$. Apart from being the leading cause of hospitalization for children, it is one of the most important chronic conditions causing elementary school absenteeism.Though environmental control measures are important to avoid or eliminate factors that induce or trigger asthma flare-ups; various formulations are available in Ayurvedic classics to manage the condition. The treatment should be aimed to remove the obstruction made by Kapha and normalize the function of Vayu. [8] The drug selected in this study are having properties to remove the obstruction made by Kapha in the Pranavaha Srotas and related system and normalize the functioning of Vayu. By virtue of Rasayana (immunomodulator) properties of drug, that regularize the Dhatwagni and promote the normal condition of the child.

Asyodhvansate Kantha (Hoarseness of voice), Muhu shwaso Muhuschaiva Avadhamyate (Intermittent chocking of breathing),

Megha-Ambu-ShitaPragvataishleshmalescha Abhivardhate (Severity increases during coudy, rainy, cold, airy and humid day/season) were the Associated complaints of Tamaka Shwasa. Present history with the chronic onset of duration 1-5 years. Progression was gradual with the seasonal and diurnal variation. On asking regarding Purva vyadhi vritta (past disease history) mother told that child were having repeated colds, cough and recurrent viral lower respiratory tract infections. On asking Kulaja vyadhi vritta (family history) no history of Tamaka shwasa (asthma), allergic manifestation and skin allergy. On asking birth history child ever breast fed for less than 6 months. Immunization was done proper as per schedule. Vaiyaktika Itivritta (personal history)- in this Aharaja (Dietic History)- diet was vegetarian, dietic habits were Vishamashana and Viruddhashana. Dominance of rasa in diet were Madhura, Amla and Lavana and dominace of guna in diet were guru, 
sheeta and snigdha and cold beverages aggravated the symptoms. In the Viharaja (life style)- Nidra (sleep) was unsatisfactory, Mal Pravruti (Bowel Habit)Irregular and current/past exposure of dust.Emotinal make up was irritative. Nidana (Triggering factors) a. Dietic (Aharaja): Vishamashana (Irrregular diet), Dvandatiyoga (Mutually antagonistic), Shitashana (cold diet), Pishtanna (fried diet) and Dadhi (Curd). b. Environmental exposure/Physical activities (Viharaja): Raja (dust), Dhuma (smoke), Vata sevana, Shitasthana Sevana (cool place) and Vega Vidharana (suppression of urges). c. Aggravating diseases (Nidanarthakara Roga): Vibandha (Constipation), Pratishyaya (Coryza), Kasa, Daurbhalya (Weakness) and Chhardi (Vomiting). General Examination: Vitally stable and oriented. Prakriti (constitution) was Vatakaphaja. Sara, Samhanana, Pramana were Madhyama. Satmya and Satva were Avara. Abhyavarana Shakti and jarana Shakti were avara. Body weight and height were $9 \mathrm{k} . \mathrm{g}$ and $72 \mathrm{c} . \mathrm{m}$. respectively. BMI $\begin{array}{lll}\text { were } \quad 17.36 & \text { k.g./m2 . Systemic }\end{array}$ examination A. Respiratory system: (a) Inspection- respiration rate 22 per minute, character of repiration Abdominothoracic, inspiration deep and expiration short. (b) Palpitation- no any deformity (c) Percussion- Resonant node (d) Auscultation-broncho-vesicular sound, Adventitious sounds- generalized wheezing was found, chest was found congested, Air entry bilaterally equal. Xray chest shows no any structural abnormality.

The treatment should be aimed to remove the obstruction made by Kapha and normalize the function of Vayu. Most of the drugs used in Chitraka haritaki avaleha having the RASA- katu, tikta, kasaya, Virya- ushna, Vipaka- katu, Guna- laghu, ruksha, tikshna. Majority of the drugs of Chitraka Haritaki Avaleha have Tikta and Katu Rasa. Therefore combination has strong Amapachana and kaphahara property along with Srotoshuddhikara and Srotomukha Shodhana and Srotomukha Vivritakara property (dilatation of channels including bronchial tree). The drug also have the rasayana properties which regularize the dhatwagni. Pharmacological properties of all drugs of chitraka haritaki avaleha having the Antiallergic, antiinflamatory, Antitussive, Expectorant, antihistaminic and immunomodulatory actions. Therefore the above drugs are useful in the treatment of Tamaka Shwasa (Bronchial Asthma) in children without any adverse reactions.

The word Tamas means darkness. In Tamaka Swasa, the patient experiences darkness in front of eyes4. Tamaka Swasa is an Amasayasamuttha Vikara. Tamaka Swasa is again divided into two types; Santhamaka and Prathamaka Swasa5. Vayu, which moves in Prathiloma gathi (reverse order) reaches the Srothas (Channels of breath), afflicts Greeva (neck) and Shiras (Head) and stimulates the Sleshma to result in Peenasa (Rhinitis). This obstructed Vata produces a series of manifestations, which includes Ghurghuraka (Wheezing sound), Atheeva theevra vegam cha swasam pranaprapeedakam (Difficulty in breathing and takes breath with a deep velocity). Patient gets tremors and Kasa (Cough). Pramoham kasamanascha sa gachathi muhurmuhu (Fainting again and again while coughing). As the 
Sleshma does not come out easily, the patient becomes Dukhitha (restless). Once the phlegm comes out, they will feel the relief. Because of the disturbance in the Kanta pradesha (Throat), there will be inability to speak properly. Na chaapi Nidram labhate (Sleep will be disturbed), on lying down posture breathing difficulty aggravates and Aaaseeno labhate saukhyam (relieves in sitting posture). Ushnam chaiva abhinandathi (Develops likeness towards hot things), excess of sweating occurs in forehead region and person becomes restless. Dried mouth and occurrence of episodes of breathing difficulty is specific to this disease. Disease aggravates when Megha (Clouds appears in sky) and exposure to Ambu (water), Sheetha (cold), Vata (Blowing wind) and Kapha vardhaka ahara vihara6. Swasaroga is diagnosed when the clinical manifestation suggests the vitiation of Vata and Kapha dosha, affliction of Rasa dhatu in Pranavaha srotas7 . Treatment of Tamaka Swasa can be understood according to four different conditions of patients. Balavaan (Strength), Durbala (Weakness), Kaphadhikyatha (Predominance of Kapha) and Vatadhikyatha (Predominance of Vata). In Kaphadhikya avastha and Rogi is Balavaan, can be given wholesome food and can be administered Vamana (Emesis) and Virechana (Purgation), followed by Dhuma (Smoking) and Leha (electuaries). Bronchial asthma is a chronic inflammatory disorder of the lower airway characterized by paroxysms of dyspnea, wheezing and coughs as a result of temporary narrowing of the bronchi by the trio of bronchospasm, mucosal edema and thick secretions8. The prevalence of asthma has increased globally for over three decades. The peak incidence is seen in the age group of 5-10 years. When compared with girls, boys suffer twice as much as them. Even the severity of illness is also more severe in them. 9 In school-going age group, it is about $2 \%$. 10The prevalence is $25.6 \%$ in 2009 which is under 18 years and near about $75 \%$ of asthma occurs in children under 5 years of age. Current estimates suggest that asthma affects 300 million people world-wide and there will be an additional 100 million people will be diagnosed by 202511 . There are various triggering factors for the causation of asthma which includes infections, exercise, weather, emotions, food and endocrine causes

\section{REFERENCES}

R.K Sharma, Bhagwan Dash. Caraka Samhita, English translation, Chowkhamba Sanskrit Series Office Varanasi,reprint edition: 2009.Volume IV.p. 128

R.K Sharma, Bhagwan Dash.Caraka Samhita, English translation, Chowkhamba Sanskrit Series Office Varanasi,reprint edition: 2009.Volume IV.p.128-132

\section{R.K Sharma, Bhagwan Dash.Caraka} Samhita, English translation, Chowkhamba Sanskrit Series Office Varanasi,reprint edition: 2009.Volume IV.p.128-132

Dr.Nisha Kumari, A text book of Roga Nidana and Vikriti Vijnana, Chaukambha Orientalia Varanasi, first edition 2016, Volume II.p.346

R.K Sharma, Bhagwan Dash.Caraka Samhita, English translation, Chowkhamba Sanskrit Series Office Varanasi,reprint edition: 2009.Volume IV.p.133 
R.K Sharma, Bhagwan Dash.Caraka Samhita, English translation, Chowkhamba Sanskrit Series Office Varanasi,reprint edition: 2009.Volume IV.p.131

Gopikrishna S, Shrinivas Acharya S, Diagnostic approach to diagnose the type of Swasa, IAMJ: Volume 6, Issue 9, September - 2018

Suraj Gupte. The Short Textbook of Pediatrics, Jaypee Brothers Medical Publishers, 12th Edition: 2016.p.441

Suraj Gupte. The Short Textbook of Pediatrics, Jaypee Brothers Medical Publishers, 12th Edition: 2016.p.441

Karen J.Marcdante, Robert M.Kliegman. Nelson Essentials of Pediatrics, Elsevier, first South Asia edition.2016.p.267

Dr.PS Byadgi, Parameswarappa's Text book of Ayurvediya Vikriti-Vijnana and Roga Vijnana, Volumell, Chaukambha publications, First edition: 2017.p.409.

Vinod K Paul, Arvind Bagga. Ghai Essential Pediatrics, CBS Publishers and Distributors Pvt Ltd, Ninth Edition: 2019.p.382

Bakhtyar Asharafi, Sonia, Vinod Bhardwaj, Importance of Panchkoladi avaleha in the management of Tamaka Swasa in children: A review, Int. J. Res. Ayurveda Pharm. 8(3), 2017.

Kimmi Seth, Nitesh Anand, An Ayurvedic Review on management of Tamaka Shwasa, International Journal of Pharma Sciences and Research (IJPSR), Vol. 7 No. 6 Jun 2016.

Bakhtyar Asharafi, Sonia, Vinod Bhardwaj, Importance of Panchkoladi avaleha in the management of Tamaka Swasa in children: A review, Int. J. Res. Ayurveda Pharm. 8(3), 2017. 